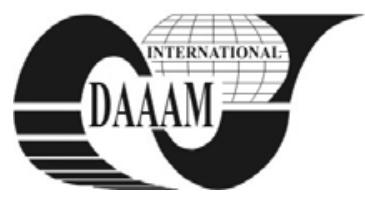

Annals of DAAAM for 2011 \& Proceedings of the 22nd International DAAAM Symposium, Volume 22, No. 1, ISSN 1726-9679 ISBN 978-3-901509-83-4, Editor B. Katalinic, Published by DAAAM International, Vienna, Austria, EU, 2011 Make Harmony between Technology and Nature, and Your Mind will Fly Free as a Bird Annals \& Proceedings of DAAAM International 2011

\title{
EFFECT OF ADHESIVE STRENGTH OF BONDED AREA SURFACE
}

\author{
OBUCINA, M[urco]; SMAJIC, S[elver] \& SKALJIC, N[edim]
}

\begin{abstract}
This paper presents the research of the impact of different types of adhesives on bond strength before planed surface of beech, fir, oak and thermally modified beech-wood $\left(220^{\circ} \mathrm{C}\right)$ samples. The samples were planed in the radial direction. Tools for planing had a double-edged, planed and the displacement at a speed of $12 \mathrm{~m} / \mathrm{min}$. The depth of the milling operation was $1.00 \mathrm{~mm}$, rake angle blade tool was $\gamma=$ $15^{\circ}$, at $6000^{\circ} / \mathrm{min}$. Diameter of the cutting edge was $\Phi=125$ $\mathrm{mm}$. The samples are glued with waterproof glue and two to $P V A c$ glue and PU glue. The lowest tensile strength of the samples were thermally treated beech glued with PVAc adhesive, then fir, oak and the largest were beech samples. The lowest tensile strength in the samples glued with PU glue had a fir, then oak and the greatest strength of had thermally modified beech and beech. The lowest shear strength had samples of thermally modified beech glued with PVAc glue, then oak, fir, and most specimens of beech. The lowest tensile strength in the samples glued with PU glue had thermally modified beech, oak and then had the greatest strength of beech and fir
\end{abstract}

Keywords: PU glue, PVAc glue, bonding, bonding strength, planing

\section{INTRODUCTION}

The technological processing of wood glue holds very important place. It significantly affects the practical value and quality of wood products. During bonding simultaneously and in parallel to place more complex physical and chemical processes, which are a consequence of the properties of wood and glue, the interaction between wood and glue, and elements of the technological process. The main goal when gluing wood to achieve a combination of high strength and long lasting strength, which in principle should not be less that the strength of the wood. The strength of the glued joint a lot depends on the interaction between wood and adhesives, and adhesion of the adhesive. The lowest tensile strength in the samples glued with PU glue had a fir, then oak and the greatest strength of had thermally modified beech and beech. The lowest shear strength had samples of thermally modified beech glued with PVAc glue, then oak, fir, and most specimens of beech. The lowest tensile strength in the samples glued with PU glue had thermally modified beech, oak and then had the greatest strength of beech and fir. In addition the adhesion properties of adhesives significantly affect the quality of surface finish and wood. Wetting (spreading glue on the surface of wood depends directly from the geometry of the surface). On the other hand, all the bumps on the surface of the wood creates an uneven layer of glue and create internal tension in the merge (pressing) of wood surfaces to be bonded. Tests show that a smooth surface requires a relatively small amount of coating for surface protection (Aydin, 2004 and Marian et al, 1958).The quality of machined surfaces of wood depends on the anatomical structure (tree species), and cutting parameters (depth of operation, velocity, displacement, rotation number of tools, interventions by the blade and blade angle. It is assumed that the surface roughness of cut surfaces softwood sawmills and increasing radius of the wedge (Kenturakis \& Juodeikiene, 2007; Gindl \& Tschegg, 2002 and Obucina et al., 2010).

\section{MATHERIALS AND METHODS}

Experimental measurements were performed on samples of oak, fir, beech and thermally modified beech. The dimensions of the original samples before planing and gluing were: 70x21x600 mm steamed beech, oak and fir, a 70x21x500 mm thermally modified beech. Moisture content of samples was: 9.18\% Steamed Beech, Fir 18.27\%, 9.31\% Oak, Thermally modified beech $4.47 \%$. Samples were radial texture, before planing were conditioned at $20^{\circ} \mathrm{C}$ and relative humidity of 65 $\pm 5 \%$. Investigations were conducted on samples who planed in the radial direction. Manufacturer of glue is Kleiberit Germany. According to technical specification glue properties are: one component D4 waterproof glue for bonding according to DIN/EN 204 KLEBIT 314 PVAc glue and PUR Leim 501 PU glue. Planing is done to PowerMat 400 machine, which had a cutting tool with two blades. Planed at the speed of displacement of $12 \mathrm{~m} / \mathrm{min}$. Planing thickness was $1.00 \mathrm{~mm}$. The number of revolutions was $6000^{\circ} / \mathrm{min}$, a rake angle $15^{\circ}$ blade. Bonding the samples was carried out in a star pres. Regimes were applied by glue manufacturer's recipe: application with the adhesive was $150 \mathrm{~g} / \mathrm{m}^{2}$, pressing pressure $0.7 \mathrm{MPa}$.

Once we have samples that are bonded out of the presses, we left them to be conditioned for seven days, before proceeding with further processing thereof. The temperature at the facility where the samples were bonded with PVAc adhesive was $19^{\circ} \mathrm{C}$ and relative humidity $49 \%$. After the samples conditioned we accessed on the crop specimens for testing shear strength and tensile strength according to EN 204. The study was carried out on Zwick testing machine.

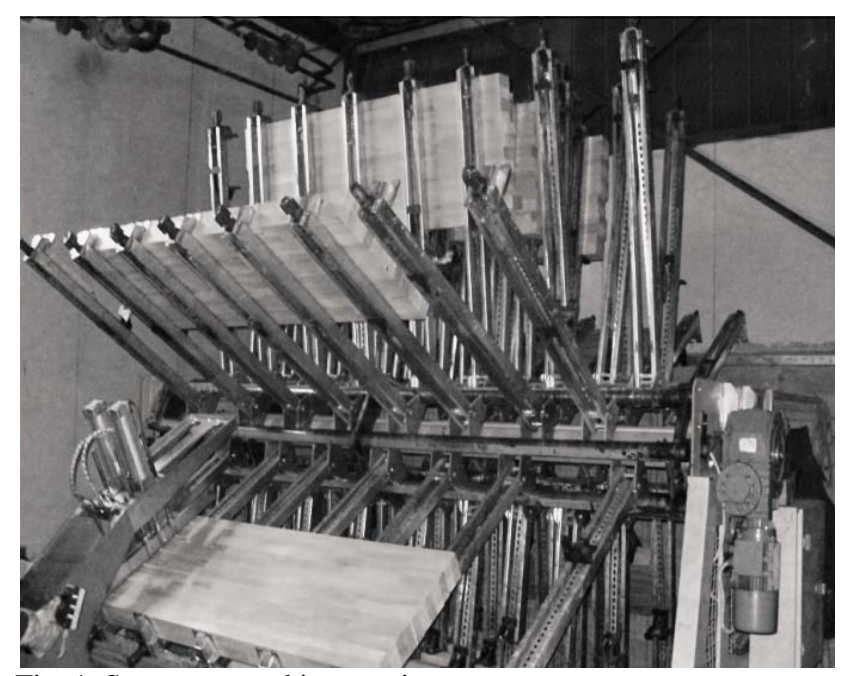

Fig. 1. Star press used in experiment 


\section{RESULTS AND DISCUSSION}

Table 1 shows the tensile strength values, which are obtained by experimental measurements, depending on the type of wood and the glue.

\begin{tabular}{|l|l|c|c|c|l|}
\hline $\begin{array}{l}\text { Type of } \\
\text { wood }\end{array}$ & $\begin{array}{l}\text { Type } \\
\text { of glue }\end{array}$ & $\begin{array}{l}\text { Number } \\
\text { of saples }\end{array}$ & $\begin{array}{l}\sigma_{\text {me }} \\
{[\mathrm{MPa}]}\end{array}$ & $\begin{array}{l}\text { St. } \\
\text { dev }\end{array}$ & Note \\
\hline \multirow{2}{*}{ Oak } & PU & 10 & 15,39 & 5,00 & tensile \\
\cline { 2 - 6 } & PVAc & 10 & 9,24 & 2,96 & tensile \\
\hline \multirow{2}{*}{ Fir } & PU & 10 & 8,28 & 1,79 & tensile \\
\cline { 2 - 6 } & PVAc & 10 & 4,98 & 1,76 & tensile \\
\hline \multirow{2}{*}{ Beech } & PU & 10 & 20,51 & 7,94 & tensile \\
\cline { 2 - 6 } & PVAc & 10 & 13,92 & 4,36 & tensile \\
\hline \multirow{2}{*}{$\begin{array}{l}\text { TT } \\
\text { Beech }\end{array}$} & PU & 10 & 14,86 & 7,95 & tensile \\
\cline { 2 - 6 } & PVAc & 10 & 0,00 & 0,00 & tensile \\
\hline
\end{tabular}

Tab. 1. Statistical values of tensile strength obtained experimentally during the testing of two types of glue

Figure 2 shows the results of tensile specimens which are glued after the previous treatment with two types of adhesives (PVAc and PU), and examined by standard methods. With the above pictures can be seen that by far the highest tensile strength of the samples were steamed beech edge PU glue, and the lowest samples of fir glued PVAc glue. Also in the picture can be seen that the tensile strength of thermally modified beech edge PVAc glue is equal to zero or it was not possible to measure.

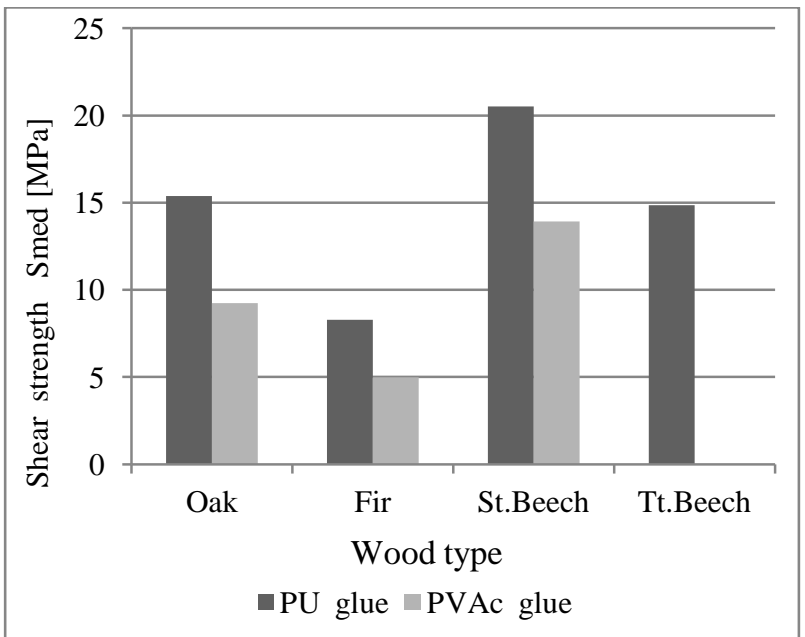

Fig. 2. Comparison of tensile strength obtained in different species of wood using different types of glue

\begin{tabular}{|l|l|c|c|c|l|}
\hline $\begin{array}{l}\text { Type of } \\
\text { wood }\end{array}$ & $\begin{array}{l}\text { Type } \\
\text { of glue }\end{array}$ & $\begin{array}{l}\text { Number } \\
\text { of saples }\end{array}$ & $\begin{array}{l}\sigma_{\mathrm{me}} \\
{[\mathrm{MPa}]}\end{array}$ & $\begin{array}{l}\text { St. } \\
\text { dev }\end{array}$ & Note \\
\hline \multirow{2}{*}{ Oak } & PU & 10 & 3,95 & 1,70 & shear \\
\cline { 2 - 6 } & PVAc & 10 & 6,14 & 1,99 & shear \\
\hline \multirow{2}{*}{ Fir } & PU & 10 & 6,47 & 1,50 & shear \\
\cline { 2 - 6 } & PVAc & 10 & 7,25 & 1,52 & shear \\
\hline \multirow{2}{*}{ Beech } & PU & 10 & 4,45 & 2,30 & shear \\
\cline { 2 - 6 } & PVAc & 10 & 11,92 & 2,93 & shear \\
\hline \multirow{2}{*}{$\begin{array}{l}\text { TT } \\
\text { Beech }\end{array}$} & PU & 10 & 2,93 & 1,26 & shear \\
\cline { 2 - 6 } & PVAc & 10 & 2,19 & 2,81 & shear \\
\hline
\end{tabular}

Tab. 2. Statistical values of shear strength obtained experimentally during the testing of two types of glue

Figure 3 shows the results obtained shear strength of samplestreated with the same glue (PU and PVAc).

We see that the samples made of steamed beech and glued PU showed the highest strength while samples made of thermally modified beech have the lowest value of shear strength. Table 2 shows the values of shear strength, which are obtained by experimental measurements, depending on the type of wood species and glue.

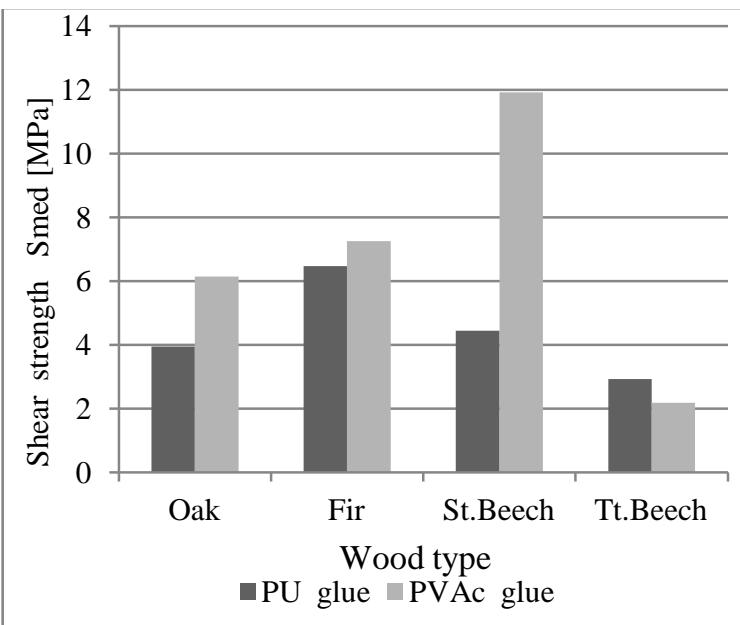

Fig. 3. Comparison of the obtained shear strength of different types of wood using different types of glue

The results of the study showed that the bonding strength of wood (shear and tensile) is affected by the type of different wood and the type of glue. In further research is planned to investigate the influence of surface treatment process (planing, sawing, sanding) on the wetting and adhesive bonding strength.)

\section{CONCLUSION}

The results showed that the samples were bonded with PVAc glue generally have greater strength than the samples bonded with PU glue. When the tensile strength shows that PVAc blend for approx. 30\% have a higher tensile strength compared to the PU compound.

When shear strength also see that the samples were bonded with PVAc glue obtained higher shear strength of approx. 18\% compared to the combination of bonded with PU glue. Second, supporting the reasons for these results and much better indicators of PVAc glue in relation to the PU glue can be traced to the physical mechanical properties of wood that is treated, characteristics of polyurethane glue. Which due to its specific requirements increased relative humidity in the room where it is used, inactivity planed surface of thermally modified wood, the internal structure of other species, and more numerous secondary factors that significantly affect the quality of glue bond.

\section{REFERENCES}

Aydin, I. (2004). Activation of wood surfaces for glue bonds by mechanicak pre-treatment and its effects on some veneer surfaces and plywod panels. Applied Surface Science, Vol. 233, Issues 1-4, pp. 268-274, ISSN 0169-4332

Gindl, M. \& Tschegg, S. (2002). Significance of the acidity of wood to the surface free energy components of different wood species. Langmuir, 18 (8), pp. 3209-3212

Keturakis, G. \& Juodeikiene, I. (2007). Investigation Of Milled Wood Surface Roughness. Materials Science (Medžiagotyra), Vol. 13, No. 1, ISSN 1392-1320

Marian, J.E.; Stumbo, D.A. \& Maxey, C.W. (1958). Surface texture of wood as related to glue-joint strenght. Forest Prod. J, Vol 12, 345-351

Obućina, M.; Smajić, S.; Škaljić, N. \& Beljo Lučić, R. (2010). Effect of Rotation Speed and Wood Species on Roughness of Machined Surface, Proceedings of the 21st International DAAAM Symposium, Zadar, ISSN 1726-9679, ISBN 978-3901509-73-5, Katalinic, B. (Ed.), pp.449-450, Published by DAAAM International, Vienna, Austria 